УДК 378.14 : 615.072 (477)

DOI 10.11603/me.2414-5998.2020.3.11438

H. O. Зарівна
ORCID https://orcid.org/0000-0002-8522-4024
ResearcherID Q-5610-2016
Scopus Author ID 57202011083

Л. С. Логойда

ORCID https://orcid.org/0000-0002-5252-8806

ResearcherID P-2227-2016

Scopus Author ID 57188934291

О. Б. Поляк

ORCID https://orcid.org/0000-0003-4765-395X

ResearcherID P-2921-2016

Scopus Author ID 57188925317

Тернопільський національний медичний університет імені І. Я. Горбачевського МОЗ Украӥни

\title{
МЕТОДИЧНІ АСПЕКТИ ВИКЛАДАННЯ СПЕЦІАЛІЗАЦІЇ «КОНТРОЛЬ ЯКОСТІ ЛІКАРСЬКИХ ЗАСОБІВ» ДЛЯ СТУДЕНТІВ ФАРМАЦЕВТИЧНОГО ФАКУЛЬТЕТУ ЗАОЧНОЇ ФОРМИ НАВЧАННЯ
}

\author{
N. O. Zarivna, L. S. Logoyda, O. B. Polyak \\ I. Horbachevsky Ternopil National Medical University
METHODOLOGICAL ASPECTS OF TEACHING SPECIALIZATION “QUALITY CONTROL OF MEDICINES” FOR STUDENTS OF \\ PHARMACEUTICAL FACULTY OF EXTERNAL FORM OF EDUCATION
}

\begin{abstract}
Анотація. У статті висвітлено шляхи вирішення основних проблем, з якими стикаються викладачі, що працюють зі студентами заочної форми навчання при викладанні спеціалізації «Контроль якості лікарських засобів». Проаналізовано основні проблеми, які можуть впливати на результативність навчання студентів заочної форми навчання. Дослідження базується на вивченні матеріалів, отриманих із відкритих джерел інформації та власного досвіду авторів. У статті наведені сучасні технології викладання та тестування студентів заочної форми навчання з контролю якості лікарських засобів, впроваджені на кафедрі фармацевтичної хімії. Оскільки якість препарату закладається ще на етапі фармацевтичної розробки, студент чітко повинен знати елементи фармацевтичної розробки та фармацевтичного аналізу. Ціллю спеціалізації «Контроль якості лікарських засобів» є: засвоїти загальні методи аналізу субстанцій лікарських речовин та підтвердження їх доброякісності за зовнішнім виглядом, розчинністю та реакцією середовища згідно з вимогами ДФУ; вивчити і пояснювати фізичні та фізико-хімічні методи аналізу органічних лікарських засобів; вміти проводити реакції ідентифікації субстанцій лікарських речовин за катіонним та аніонним складом згідно з вимогами ДФУ; використовувати хімічні методи для ідентифікації лікарських засобів органічної структури за аналітико-функціональними групами; визначати фізичні константи органічних речовин для ідентифікації та встановлення чистоти лікарських засобів; використовувати визначення показника заломлення і питомого обертання розчинів лікарських засобів для їх ідентифікації і встановлення чистоти; практикувати загальні вимоги ДФУ щодо випробувань на граничний вміст домішок; вміти проводити кількісне визначення вмісту лікарських речовин у субстанції різними методами; вміти проводити якісний та кількісний експрес-аналіз діючих речовин в екстемпоральних лікарських засобах та валідацію аналітичних методик. Детальне і грунтовне ознайомлення з основами контролю якості лікарських засобів дає можливість більш повно засвоїти матеріал, що вивчається, реалізувати науковотворчий потенціал студентів, збагачує їх знаннями, які безпосередньо будуть використані в їхній практичній діяльності. Запропонований метод дозволяє викладачеві успішніше будувати освітній процес, що, в кінцевому підсумку, позитивно позначається на загальному засвоєнні курсу.
\end{abstract}

Ключові слова: контроль якості лікарських засобів; фармацевтична розробка; фармацевтичний аналіз; Фармакопея.

Abstract. The article adduces the ways to solve the main problems faced by teachers working with students of pharmaceutical faculty of external form of learning in teaching of control quality of medicines; analyzes the main issues that can affect the performance of the teaching of external form of education. The research is based on the study of materials obtained from open sources of information and authors' own experience. The article presents modern technologies of teaching and testing of students on Quality control of medicines, approved at the Department of Pharmaceutical Chemistry. Since the quality of the drug is laid down at the stage of pharmaceutical development, the student must clearly know the elements of pharmaceutical development and pharmaceutical analysis. The purpose

( Н. О. Зарівна, Л. С. Логойда, О. Б. Поляк 
of control quality of medicines is to: learn general methods of analysis of substances of medicinal substances and to determine their qualities in appearance, solubility and reaction of the environment in accordance with the requirements of the State Pharmacopoeia (SPhU); to study and explain the physical and physico-chemical methods of analysis of organic medicinal products; to be able to carry out reactions of identication of substances of medicinal substances by cations and anions in accordance with the requirements of SPhU; to use chemical methods for the identication of medicinal products of organic structure by analytical-functional groups; to determine the physical constants of organic substances for the identication and purication of medicinal products; to use the denition of refractive index and spefic rotation of solutions of drugs for their identication and purity; to practice the general requirements of the SPhU for the testing of the maximum content of impurities; to be able to quantify the content of medicinal substances in the substance by different methods; to be able to conduct qualitative and quantitative rapid-analysis of active substances in extemporal dosage forms and validation of analytical methods. Detailed and thorough acquaintance with the basics of the discipline of Control quality of medicines, gives the opportunity to more fully master the studied material, realize the scientific and creative potential of students, enrich their knowledge, which will be directly used in their practical activities. The proposed method allows the teacher to successfully build an educational process, which ultimately positively affects the overall mastering of the course.

Key words: quality control of medicines; pharmaceutical development; pharmaceutical analysis; Pharmacopoeia.

Вступ. Сучасна система вищої освіти ставить завдання - вдосконалювати форми і методи навчання, максимально наближати його організацію до сучасних вимог, дати кожному студенту якісну освіту та можливість бути конкурентоспроможними на ринку праці. Пріоритетним напрямом держави у розвитку вищої школи є особиста орієнтація, постійне підвищення якості освіти, оновлення ії̈ змісту і форм, запровадження нових освітніх технологій тощо. Реформування системи вищої освіти згідно з європейськими стандартами змушує переглянути зміст, форми, методи і засоби навчання. Саме це зумовило необхідність переходу вищої школи до нової кредитно-модульної системи організації навчального процесу, що, у свою чергу, приведе до зростання інтелектуального та творчого потенціалу студентів.

Мета статті - вивчення методичних аспектів викладання дисципліни «Контроль якості лікарських засобів» для студентів фармацевтичного факультету заочної форми навчання (спеціальність 226 «Фармація, промислова фармація»).

Теоретична частина. Навчальна дисципліна спеціалізація «Контроль якості лікарських засобів» належить до циклу дисциплін професійно-орієнтованої підготовки фахівців за напрямом «Фармація». Лікарські засоби $є$ продуктами, від яких безсумнівно залежить здоров’я, а часто життя людини, тому контроль якості у сфері лікарських засобів має завжди проводитися на належному рівні відповідними органами державної виконавчої влади в межах повноважень, визначених законодавством України [1-3].

Мета викладання даної дисципліни передбачає сформувати систему знань і вмінь, які однозначно дадуть можливість майбутньому фахівцю фармацевтичної галузі повноцінно і якісно виконувати свої професійні обов'язки у сфері контролю якості лікарських засобів та стати конкурентоспроможними на ринку праці.
Під час викладання даної дисципліни закладаються теоретичні основи вивчення студентами фармацевтичної системи якості, яка передбачає контроль якості лікарських засобів на стадії розробки, дослідження, зберігання та споживання згідно 3 існуючими методиками контролю якості та вимогами в системах GMP/GLP, GCP, GPP, GDP [4-8], що забезпечується використанням різних випробувань: фізичних, фізико-хімічних, хімічних, теоретичні основи яких були прочитані студентам ще на другому курсі при вивченні дисциплін «Аналітична хімія» та «Фізичні методи аналізу і метрологія».

На практичних заняттях студенти знайомляться 3 основами державної політики і управління у сфері контролю якості лікарських засобів. Вивчають Державну Фармакопею України (ДФУ) - конституцію ліків, гармонізовані настанови з якості, закони, стандарти, кодекси усталеної практики, належні практики, за допомогою яких проводиться оцінка якості фармацевтичних препаратів. Також набувають навичок із розробки специфікацій на лікарські засоби залежно від виду лікарської форми. Вибирають основні та додаткові показники якості лікарських засобів, проводять фармако-технологічні випробування згідно з редакцією ДФУ. Готові лікарські засоби перевіряють також на якісний склад та кількісний вміст активних фармацевтичних інгредієнтів різними фармакопейними методами аналізу, в результаті чого вибирають маркери якості та критерії прийнятності. Потреба гарантувати достовірність отриманих результатів кількісного визначення вимагає валідації аналітичних методик за загальноприйнятими валідаційними характеристиками і застосування законів математичної статистики, що успішно студентами на занятті викладається.

Оскільки якість препарату закладається ще на етапі фармацевтичної розробки, студент чітко повинен знати елементи фармацевтичної розробки. Ціль фармацевтичної розробки - розробити якісний 
препарат і процес його виробництва, щоб постійно випускати продукцію із заданими функціональними характеристиками та конкурентоспроможністю на фармацевтичному ринку [7, 8].

Детальне і грунтовне ознайомлення з основами спеціалізації «Контроль якості лікарських засобів» дає можливість більш повно засвоїти матеріал, що вивчається, реалізувати науково-творчий потенціал студентів, збагачує їх знаннями, які безпосередньо будуть використані в їхній практичній діяльності [1-3].

Для освоєння матеріалу виділено 18 год лекцій, 30 год практичних занять, 180 год самостійної роботи студентів (СПРС). Така невелика кількість аудиторних годин вимагає від викладача дуже ретельного підходу до підбору навчального матеріалу та методики його викладання, яке включає в себе велику кількість різноманітних прийомів, зокрема спілкування з викладачем на практичних, семінарських і лекційних заняттях, а також допомогу студентові при виконанні самостійної роботи. Проведення досліджень під час практичного заняття та обгрунтування одержаних результатів, використавши теоретичні знання, значно підвищує якість засвоєння матеріалу. При вивченні даної дисципліни студентам читаються лекції з мультимедійним супроводом, які сприяють всебічному сприйняттю викладеного матеріалу та більш повному його засвоєнню. На лекцію студенти приходять підготовленими, оскільки матеріали підготовки до лекцій розміщені на Web-порталі університету.

Практичні заняття з даної дисципліни проводяться згідно з методикою «єдиного дня», відповідно до якої навчання студентів заочної форми навчання становить 6 робочих днів, з яких 1 день призначений для лекцій та 5 днів - для практичних занять. Теми практичних наведені нижче: 1. Управління якістю у фармацевтичній галузі. Галузеві стандарти GMP, GLP, GDP, GPP; 2. Шляхи створення нових лікарських засобів. Зв'язок структура - біологічна активність. Принципова схема розробки нового лікарського засобу. Найуспішніші лікарські засоби XX-XXI ст.; 3. Хроматографічні методи дослідження: хроматографія в тонких шарах сорбенту (ТШХ), високоефективна рідинна (ВЕРХ), ультрависокоефективна рідинна хроматографія (УВЕРХ), ВЕРХ з мас-селективним детектуванням аналітів, газорідинна хроматографія (ГРХ) та їх використання у хіміко-токсикологічному аналізі; 4. Валідація як важлива складова фармацевтичного аналізу. Валідація аналітичних та біоаналітичних методик; 5. Специфікації: методи випробувань та критерії прийнятності.

У результаті вивчення дисципліни «Контроль якості лікарських засобів» студент повинен знати: сучасний стан та пріоритетні напрямки шляхів пошуку нових лікарських засобів; методи синтезу субстанцій лікарських речовин; закономірність зв'язку хімічної будови лікарських речовин з їх фізичними, хімічними та фармакологічними властивостями; методи встановлення будови новосинтезованих речовин; здійснювати емпіричний та направлений пошук ліків; систему функціонування контролю якості фармацевтичної продукції; структуру Державної Фармакопеї України; використання органолептичних показників якості, фізичних, фізикохімічних та хімічних методів при розробці методик контролю якості для оцінки якості фармацевтичної продукції; особливості розробки методик контролю якості лікарських засобів аптечного та промислового виготовлення; особливості розробки методик контролю якості на лікарські засоби рослинного походження; валідацію методик аналізу; основні валідаційні параметри та їх характеристику; проведення процедури валідації; верифікацію аналітичних методик; суть та призначення.

У результаті вивчення дисципліни «Контроль якості лікарських засобів» студент повинен вміти: здійснювати емпіричний та направлений пошук ліків; встановлювати залежність зв'язку між хімічною будовою та дією речовини на організм, а також залежність фармакологічної дії від фізичних та хімічних властивостей лікарських речовин; удосконалювати схеми синтезу та технологію виробництва лікарських речовин; користуватися нормативною документацією, яка регламентує якість лікарських засобів у своїй професійній діяльності (ДФУ, Міжнародна фармакопея, національні та регіональні фармакопеї, МКЯ, відповідні накази та інструкції); користуватися галузевими стандартами, методичними вказівками при здійсненні методів контролю якості субстанцій та лікарських препаратів; використовувати хімічні, фізичні, фізикохімічні методи при контролі якості субстанцій ЛР і ГЛЗ; розробляти методики визначення параметрів якості лікарських засобів (ідентифікація, випробування на чистоту, кількісне визначення); проводити валідацію аналітичних методик; провести випробування, що стосується визначення основних валідаційних параметрів; проводити процедуру валідації; визначити критерії невизначеності аналітичної методики; провести необхідні розрахунки, 
використавши підхожі методи статистики; зробити висновки щодо проведення валідації при розробці відповідних методик аналізу; зробити висновок про правильність аналізу; провести верифікацію аналітичної методики згідно з редакцією ДФУ.

Кожне практичне заняття забезпечене методичними рекомендаціями, матеріалами підготовки до практичного заняття, тестовими завданнями для контролю знань, ситуаційними задачами та методичними вказівками для самостійної роботи студентів. Також для кожної теми заняття викладачі використовують реальні приклади з практичної фармації щодо контролю якості лікарських засобів, пов’язані з вивченим теоретичним матеріалом, які студенти оформляють у робочі протоколи, де записують одержані результати та аналізують висновки. Системність ведення протоколів та дотримання вимог щодо їх оформлення враховується при комплексному підході оцінювання. У кінці семестру передбачено диференційований залік.

Викладачі постійно працюють над удосконаленням необхідного навчально-методичного забезпечення дисципліни, прагнуть домогтися засвоєння знань, практичних навичок, сприяють формуванню наукового світогляду, моральних, естетичних та інших якостей особистості, вихованню колективу. Також орієнтуються на потреби студента у певних знаннях, уміннях і навичках з опорою на подальшу самоосвіту, оскільки в навчальному закладі не закінчується формування особистості спеціаліста, воно продовжується все життя впродовж

\section{Список літератури}

1. Державна Фармакопея України: в 3 т. / Державне підприємство «Український науковий фармакопейний центр якості лікарських засобів». - 2-ге вид. - Х. : Державне підприємство «Український науковий фармакопейний центр якості лікарських засобів», 2015. T. 1. -1128 c.

2. Державна Фармакопея України: в 3 т. / Державне підприємство «Український науковий фармакопейний центр якості лікарських засобів». - 2-ге вид. - Х. : Державне підприємство «Український науковий фармакопейний центр якості лікарських засобів», 2014. T. 2. -724 с.

3. Державна Фармакопея України: в 3 т. / Державне підприємство «Український науковий фармакопейний центр якості лікарських засобів». - 2-ге вид. - Х. : Державне підприємство «Український науковий фармакопейний центр якості лікарських засобів», 2014. T. 3. - 732 с. практичної діяльності і безперервного підвищення кваліфікації.

Висновки та перспективи подальших досліджень. Узагальнюючи вищесказане, «контроль якості лікарських засобів» - це дисципліна, яка формує систему знань і вмінь, які однозначно дадуть можливість майбутньому фахівцю фармацевтичної галузі повноцінно і якісно виконувати свої професійні обов'язки у сфері контролю якості лікарських засобів та стати конкурентоспроможними на ринку праці. Під час викладання даної дисципліни закладаються теоретичні основи вивчення студентами фармацевтичної системи якості, яка передбачає контроль якості лікарських засобів на стадії розробки, дослідження, зберігання та споживання згідно з існуючими методиками контролю якості та вимогами в системах GMP/GLP, GCP, GPP, GDP, що забезпечується використанням різних випробувань. Аналіз та введення у педагогічну діяльність теоретично обгрунтованих сучасних положень, нових прийомів та методів дозволять студентам систематизувати отримані знання, практичні навички і їх використання у майбутній професійній діяльності. Наступним етапом дослідження буде подання теоретичних основ нових методів аналізу та їх застосування у практиці, що дозволять студентам проводити контроль якості готових лікарських засобів на вищому рівні та повністю забезпечать їм належний рівень підготовки в галузі фармацевтичного аналізу і конкурентоспроможність на міжнародному ринку праці.

4. Фармацевтичний аналіз : навч. посіб. для студ. вищ. навч. закл. / [П. О. Безуглий, В. А. Георгіянц, І. С. Гриценко та ін.] ; за заг. ред. В. А. Георгіянц. - Х. : НФаУ: Золоті сторінки, 2013. - 552 с.

5. Absorption spectrophotometry, ultraviolet and visible / European Pharmacopoeia. 7th edition /European Directorate for the Quality of Medicines (EDQM). - Council of Europe, 67075 Strasbourg Cedex, France, 2009. - P. 40-41.

6. Drug development and industrial pharmacy / M. S. Rahman, A. Babar, N. K. Patel, F. M. Plakogiannis. - 1990. Vol. 16 (4). - P. 651-672.

7. Panagopoulou A. Drug development / A. Panagopoulou, M. Georgarakis. - 1990. - Vol. 16 (4). - P. 637-649.

8. WHO Good Practices for Pharmaceutical Quality Control Laboratories. Working document QAS/09.296. 2009. - Rev. 1. - P. 34. 


\section{References}

1. (2015). Derzhavna Farmakopeia Ukrainy: v 3 t. Derzhavne pidpryiemstvo "Ukrainskyi naukovyi farmakopeinyi tsentr yakosti likarskykh zasobiv". 2-e vyd. [State Pharmacopoeia of Ukraine: in 3 vol. State Enterprise "Ukrainian Scientific Pharmacopoeia Center for the Quality of Medicines”. 2nd edition]. Kharkiv: Derzhavne pidpryiemstvo "Ukrainskyi naukovyi farmakopeinyi tsentr yakosti likarskykh zasobiv” [in Ukrainian].

2. (2014). Derzhavna Farmakopeia Ukrainy: $v 3 t$. Derzhavne pidpryiemstvo "Ukrainskyi naukovyi farmakopeinyi tsentr yakosti likarskykh zasobiv". 2-e vyd. [State Pharmacopoeia of Ukraine: in $3 \mathrm{vol}$. State Enterprise "Ukrainian Scientific Pharmacopoeia Center for the Quality of Medicines”. 2nd edition]. Kharkiv: Derzhavne pidpryiemstvo "Ukrainskyi naukovyi farmakopeinyi tsentr yakosti likarskykh zasobiv" [in Ukrainian].

3. (2014). Derzhavna Farmakopeia Ukrainy: $v 3 t$. Derzhavne pidpryiemstvo "Ukrainskyi naukovyi farmakopeinyi tsentr yakosti likarskykh zasobiv". 2-e vyd. [State Pharmacopoeia of Ukraine: in 3 vol. State Enterprise "Ukrainian Scientific Pharmacopoeia Center for the
Quality of Medicines”. 2nd edition]. Kharkiv: Derzhavne pidpryiemstvo "Ukrainskyi naukovyi farmakopeinyi tsentr yakosti likarskykh zasobiv” [in Ukrainian].

4. Bezuhlyi, P.O., Heorhiiants, V.A., \& Hrytsenko, I.S. (2013). Farmatsevtychnyi analiz: navch. posib. dlia stud. vyshch. navch. zakl. [Pharmaceutical analysis: teaching. manual for the stud higher teach shut up]. Heorhiiants, V.A. (Ed.). Kharkiv: NFaU “Zoloti storinky” [in Ukrainian].

5. (2009). Absorption spectrophotometry, ultraviolet and visible. European Pharmacopoeia. 7th edition. European Directorate for the Quality of Medicines (EDQM). Council of Europe, 67075 Strasbourg Cedex, France.

6. Rahman, M.S., Babar, A., Patel, N.K., \& Plakogiannis, F.M. (1990). Drug development and industrial pharmacy. 16 (4), 651-672.

7. Panagopoulou, A., \& Georgarakis, M. (1990). Drug development, 16 (4), 637-649.

8. (2009). WHO Good Practices for Pharmaceutical Quality Control Laboratories. Working document QAS/09.296. 